\title{
INOVASI SISTEM PENDIDIKAN
}

\author{
Muhammad Anwar HM. \\ Fakultas Tarbiyah dan Keguruan \\ Universitas Islam Negeri Alauddin Makassar \\ Email: muhanwar.tarbiyah@uin-alauddin.ac.id
}

\begin{abstract}
Education is everything. Good civilization is one result of good education. When a community wants to achieve its goals well, education is the key to the answer. However, along with the changing times and times, education also changes in the patterns and methods of teaching. In addition, age, place, technological sophistication also forms learning patterns in education. Therefore, as time goes on as well as the demands of the times faced, it is very necessary for innovation in education itself. This is merely to meet the needs of the community as the main element in the education system. The writing below illustrates the importance of education in accordance with its stages and at the same time the demand for innovation.
\end{abstract}

Keywords: Education, Innovation, Human Resources

\section{PENDAHULUAN}

$\mathrm{P}$ erkembangan ilmu pengetahuan dan teknologi telah membawa perubahan yang sangat signifikan pada berbagai dimensi kehidupan manusia, baik dalam kehidupan ekonomi, sosial, budaya maupun pendidikan. Perubahan tersebut banyak membawa manfaat, tetapi di sisi lain juga membawa manusia ke persaingan global yang semakin ketat. Karena itu agar mampu berperan dalam persaingan global, perlu diupayakan pengembangan dan peningkatan kualitas sumber daya manusia (SDM). SDM merupakan prasyarat mutlak untuk mencapai tujuan pembangunan bangsa.

Salah satu wahana untuk meningkatkan kualitas SDM, peran pendidikan sangat dibutuhkan, sebab pendidikan merupakan sarana untuk membangun watak bangsa (Nation Character Building). Oleh karena itu, kualitas pendidikan harus senantiasa ditingkatkan sebab masyarakat yang cerdas akan memberi nuansa kehidupan yang cerdas pula dan secara progresif akan membentuk kemandirian. Dapat dikatakan eksistensi dan daya survival suatu bangsa sangat ditentukan oleh kualitas SDM yang dimiliki bangsa tersebut. Semakin tinggi kualitas SDM suatu bangsa, makin eksis bangsa tersebut, sebaliknya semakin rendah kualitas SDM suatu bangsa, pertanda semakin bergantungnya bangsa tersebut terhadap bangsa lain. ${ }^{1}$

${ }^{1}$ Jacques Attali (1991) seorang penulis berkebangsaan Perancis, dalam buku Millenium: Winners and Lossers in the Coming World Order baranggapan bahwa memasuki millennium ketiga, manusia tersegmentasi menjadi dua kelompok besar, yakni kelompok pemenang (the winners) dan kelompok 
Sebagai salah satu negara berkembang, kualitas SDM bangsa Indonesai terhitung rendah, sehingga ketergantungan Indonesia terhadap negara-negara maju bisa dikatakan sangat tinggi. ${ }^{2}$ Rendahnya kualitas SDM ini salah satunya diakibatkan rendahnya mutu pendidikan jika dibanding dengan Negara lain. Jika dilihat secara lebih spesifik lagi dalam proses pembelajaran, terbukti hasil-hasil pengajaran dan pembelajaran di berbagai bidang studi selalu kurang memuaskan berbagai fihak (stakeholder).

Hal itu disebabkan dua hal: pertama, perkembangan kebutuhan dan aktivitas di berbagai bidang kehidupan selalu meninggalkan proses/hasil kerja lembaga pendidikan atau melaju terlebih dahulu dibanding dengan proses pengajaran dan pembelajaran. Akibatnya hasil-hasil pengajaran dan pembelajaran tidak sesuai dengan kenyataan kehidupan yang diarungi siswa. Kedua, pandangan dan temuan baru tentang pembelajaran dan pengajaran membuat paradigma, falsafah, dan metodologi pembelajaran yang ada saat ini tidak memadai atau tidak cocok lagi. ${ }^{3}$

Berbagai permasalahan dan kenyataan negatif tentang hasil pendidikan dan pengajaran diatas menuntut adanya pembaharuan pendidikan, sehingga diharapkan mutu dan hasil pendidikan semakin baik dan meningkat. Pembaharuan (inovasi) pendidikan tersebut dilakukan supaya pendidikan dapat selalu adaptif terhadap perubahan dan perkembangan zaman, sekaligus agar tidak terjadi kesenjangan antara idealitas dan realitas.

\section{URGENSI INOVASI SISTEM PENDIDIKAN}

Inovasi merupakan suatu ide, gagasan, praktik atau obyek/benda yang disadari dan diterima sebagai suatu hal yang baru oleh seseorang atau kelompok untuk diadopsi. ${ }^{4}$ Inovasi pada dasarnya merupakan hasil pemikiran cemerlang yang bercirikan hal baru bisa berupa praktik-praktik tertentu ataupun berupa produk dari suatu hasil olah pikir dan olah teknologi yang diterapkan melalui tahapan tertentu, yang diyakini dan

pecundang (the Lossers). Kelompok pemenang adalah mereka yang terdidik (educated), otonom secara peribadi, berketrampilan, berdaya adaptibilitas tinggi, memiliki kemampuan ekonomi kuat, dan menguasai multiakses. Adapun ciri-ciri the Lossers ditandai dengan kemampuan ekonomi rendah, berpendidikan rendah, tidak dimiliki keterampilan professional yang memadai, akses informasi terbatas, underestimate, daya adaptasi rendah, gizi dan kesehatan yang memprihatinkan, dan tempat bermukim yang seadanya. Lihat: Rohadi Wicaksono, "Mengapa Harus Konstruktivistik", dalam http//www.artikelpendidikan.com (19 Juli 2017).

2 Menurut catatan Human Development Report tahun 2003 versi UNDP Human Development Indek (HDI) atau kualitas sumber daya manusia Indonesia berada di peringkat 112 dari 126 negara, dan satu peringkat di bawah Vietnam. Indonesia berada jauh dibawah Filipina (85), Thailand (74), Malaysia (58), Brunei Darussalam (31), Korea Selatan (30) dan Singapura (28). Lihat: Nurhadi dan Agus Gerrad Senduk, Pembelajaran Kontekstual dan Penerapannya dalam KBK (Malang: Penerbit Universitas Negeri Malang, 2003), h. 1.

3 Luk-luk Nur Mufidah, "Pembelajaran Kuantum yang Menyenangkan”, dalam http: //pakb.wordpress (2 April 2018)

${ }^{4}$ Inovasi juga berarti suatu perubahan baru menuju ke arah perbaikan atau berbeda dari yang ada sebelumnya, dilakukan dengan sengaja dan berencana. Fuad Ihsan, Dasar-dasar Kependidikan, (Jakarta: Rineka Cipta, 2005), h. 191. 
dimaksudkan untuk memecahkan persoalan yang timbul dan memperbaiki suatu keadaan tertentu ataupun proses tertentu yang terjadi di masyarakat.

Dengan demikian yang dimaksud inovasi pendidikan adalah inovasi dalam pendidikan untuk memecahkan masalah-masalah pendidikan. Inovasi ini dapat berupa ide, barang, metode yang dirasakan atau diamati sebagai hal baru bagi seseorang atau sekelompok orang (masyarakat) yang digunakan untuk mencapai tujuan pendidikan atau untuk memecahkan masalah-masalah pendidikan. ${ }^{5}$

Telah banyak usaha yang dilakukan untuk kegiatan yang sifatnya pembaruan atau inovasi dalam pendidikan. Pada dasarnya inovasi pendidikan itu sendiri telah melalui berbagai tahap sebagaimana diidentifikasi oleh Ashby sebagai berikut: Tahap pertama terjadi ketika pendidikan anak dilakukan secara langsung oleh orang tua. Pada tahap ini lembaga pendidikan sekolah belum ada dan media yang digunakan juga masih sangat primitif. Materi pelajarannya pun sebatas pengetahuan orang tua berdasarkan pengalaman yang mereka miliki.

Tahap Kedua terjadi ketika masyarakat/orang tua mulai sibuk dengan peran di luar rumah sehingga tugas pendidikan anak sebagian digeser dari orang tua pindah ke guru atau dari rumah ke sekolah. Pada tahap ini mulai muncul profesi guru. Tahap Ketiga ditandai dengan adanya penemuan alat untuk keperluan percetakan yang mengakibatkan lebih luasnya ketersediaan buku. Tahap keempat terjadi sebagai akibat ditemukannya bermacam-macam alat elektronika yang bisa menunjang proses belajar siswaseperti radio, telepon, TV, computer, LCD proyektor, perekan internet, LAN, dan sebagainya. ${ }^{6}$

Berdasarkan tahapan-tahapan di atas dapat dikatakan bahwa pada saat ini telah terjadi tahap keempat inovasi pendidikan yang ditandai dengan adanya pemanfaatan teknologi canggih baik perangkat lunak (software) maupun perangkat keras (hardware) dalam proses pembelajaran. Tujuan utama aplikasi teknologi baru itu adalah untuk mewujudkan proses pembelajaran yang berkualitas sehingga dapat meningkatkan kompetensi, kemampuan, keterampilan dan daya saing perserta didik dalam suatu program pendidikan pada jenjang, jenis maupun jalur tertentu. ${ }^{7}$ Inovasi pada tahap ini tentu saja bukan merupakan tahapan terakhir pembaharuan pendidikan, sebab pembaruan itu harus terus-menerus dilakukan tanpa memiliki ujung akhir. Persoalan pendidikan senantiasa ada selama peradaban dan kehidupan manusia itu ada sehingga pembaharuan pendidikan tidak akan pernah diakhiri.

Terlebih lagi dalam abad informasi seperti saat ini tingkat obsolescence dari program pendidikan di Indonesia menjadi sangat tinggi. Hal ini dapat terjadi karena

\footnotetext{
5 Ibrahim, Inovasi Pendidikan, (Jakarta: Departemen Pendidikan dan Kebudayaan, Direktorat Pendidikan Tinggi, 1988), 51. JURNAL FALASIFA. Vol. 1 No.1 Maret 2011

${ }^{6}$ Aric Ashby, The Fourth Revolution, Instructional Technology in Higher Education, (New York: Carnegie Commision in Higher Education, 1972).

${ }^{7}$ Bambang Warsita, Teknologi Pembelajaran, Landasan dan Aplikasinya, (Jakarta: Rineka Cipta, 2008), 297.
} 
perkembangan teknologi yang digunakan oleh masyarakat dalam sistem produksi barang dan jasa yang begitu cepat. Dunia produksi dapat mengembangkan teknologi dengan kecepatan yang amat tinggi karena harus bersaing dengan pasar ekonomi secara global, sehingga perhitungan efektivitas dan efesiensi harus menjadi pilihan utama.

Sebaliknya dunia pendidikan tidak dapat dengan mudah mengikuti perkembangan teknologi yang terjadi di masyarakat, disebabkan sangat sulit diterapkannya perhitungan-perhitungan ekonomi yang mendasarkan pada prinsip efektivitas dan efesiensi terhadap semua unsurnya. Tidak semua pembaharuan pendidikan dapat dihitung atas dasar efesiensi dan untung rugi karena pendidikan memiliki misi penting yang sulit dinilai secara ekonomi, yakni misi kemanusiaan. ${ }^{8}$

Perlu ditekankan bahwa pendidikan adalah ilmu normatif, maka fungsi institusi pendidikan adalah menumbuh kembangkan subyek didik ke tingkat normatif yang lebih baik, dengan cara/jalan yang baik, serta dalam konteks yang positif. Oleh karena itu, inovasi apa pun yang dilakukan dalam pendidikan tidak semata-mata atas pertimbangan efektivitas dan efesiensi, tetapi harus tetap mengacu pada upaya pembentukan manusia sejati yang memiliki kesadaran terhadap realitas dan mampu bertindak mengatasi dunia serta realitas yang dihadapinya. Sehingga dapat dihasilkan manusia yang mampu menggeluti dunia dan realitas dengan penuh sikap kritis dan daya cipta, dan itu berarti manusia mampu memahami keberadaan dirinya.

Dengan kata lain inovasi dalam pendidikan masih sangat diperlukan dalam upaya menghasilkan sistem pendidikan yang mampu menghasilkan generasi yang memiliki kecerdasan nalar, emosional, dan spiritual, bukan manusia yang kerdil, pasif, dan tidak mampu mengatasi persoalan yang dihadapi.

\section{BENTUK-BENTUK INOVASI SISTEM PENDIDIKAN}

Model-model inovasi pendidikan telah banyak dilontarkan dalam berbagai bentuk, tujuannya untuk memecahkan persoalan-persoalan yang dihadapi, antara lain: usaha pemerataan pendidikan, peningkatan mutu, peningkatan efisiensi dan efektifitas pendidikan, dan relevansi pendidikan. Kesemuanya dimaksudkan agar inovasi yang dilakukan bisa diadopsi dan dimanfaatkan untuk perbaikan dan pemecahan persoalan pendidikan di Indonesia. Dari sekian upaya itu terdapat dua isu utama yang perlu disoroti yaitu pembaruan kurikulum, dan peningkatan kualitas pembelajaran. ${ }^{9}$

Kurikulum pendidikan harus komprehensif dan responsif terhadap dinamika sosial, relevan dan tidak overload, serta mampu mengakomodasi keberagaman keperluan dan kemajuan teknologi. Sedangkan kualitas pembelajaran harus ditingkatkan untuk meningkatkan kualitas hasil pendidikan. Untuk itu secara mikro harus ditemukan metode atau pendekatan pembelajaran yang lebih efesien di kelas dan lebih

\footnotetext{
${ }^{8}$ Suyanto \& Djihad Hisyam, Refleksi dan Reformasi Pendidikan di Indonesia Memasuki Milenium III, (Yogyakarta: Adicita Karya Nusantara, 2000), 18.

${ }^{9}$ Nurhadi dan Agus Gerrad Senduk, Pembelajaran...., 2
} 
memberdayakan potensi siswa. Kedua hal inilah yang menjadi fokus inovasi pendidikan di Indonesia.

\section{A. Inovasi dalam kurikulum}

Dalam rangka memperbaiki mutu pendidikan nasional pemerintah telah melakukan berbagai usaha, salah satunya dengan penyempurnaan kurikulum. ${ }^{10}$ Langkah ini harus dilakukan guna merespon tuntutan terhadap kehidupan berdemokrasi, globalisasi dan otonomi daerah. Adapun bentuk inovasi kurikulum itu adalah dengan merubah pola penyelenggaraan pendidikan yang sentralistik, monolitik dan uniformistik, menjadi lebih demokratis. Selama ini keputusan-keputusan pendidikan selalu dilaksanakanberdasarkan hierarkhi birokrasi yang terkesan otoriter sehingga pihak bawahan harus melaksanakan seluruh keinginan pihak atasan.

Kurikulum yang bersifat sentralistik seperti ini dirasa sangat menghambat inovasi dan mempengaruhi out put pendidikan, sebab kurikulum yang terpusathanya akan menghasilkan out put manusia robot tanpa inisiatif. ${ }^{11}$ Oleh karena itu berdasarkan amanah Undang-undang Sistem pendidikan Nasional nomor 20 tahun 2003 pasal 4 dan pasal 11 maka pendidikan sekarang menganut sistem desentralistik dan lebih demokratis. $^{12}$

Konsekwensi dari desentralisasi itu adalah diterapkannya kurikulum yang berbasis kompetensi (competency based curriculum) sebagai penyempurnaan dari kurikulum sebelumnya yang cenderung berorientasi pada isi (content based curriculum). Kurikulum perlu dikembangkan dengan pendekatan berbasis kompetensi agar lulusan pendidikan nasional memiliki keunggulan kompetitif dan komparatif sesuai standar mutu nasional dan internasional. Dengan kompetensi sebagai dasar pengembangan kurikulum akan dijamin adanya fleksibilitas dalam pencapaian penguasaan kompetensi. Pendekatan ini menekankan identifikasi kompetensi dasar setiap bidang studi yang indikator-indikatornya dapat membantu guru menentukan strategi dan teknik pengajarannya.

${ }^{10}$ Kurikulum disini tidak bias diartikan sebatas subjek pelajaran saja tetapi mencakup berbagai aktifitas yang dilakukan baik di sekolah maupun di luar sekolah sebagaimana diungkapkan oleh Saylor dan Alexander: "...School curriculo is the total of the school to bring about desired outcome's in school and in out of the situation. In short the curriculum is the school's program for learners", Galen J Saylor and Alexander M. William. Curriculum Planing for Better teaching and Learning. (New York: Holt, Rinchat, 1960), 4.

${ }^{11}$ Lihat: Haidar Putra Daulay, Pendidikan Islam dalam Sistem Pendidikan Nasional di Indonesia, (Jakarta: Prenada media, 2004), 206.

12 Pasal 4 (1) menegaskan bahwa pendidikan harus diselenggarkan secara demokratis dan berkeadilan serta tidak diskriminatif dengan menjunjung tinggi hak asasi manusia, nilai keagamaan, nilai cultural dan kemajemukan bangsa. Adapun pasal 11 (1) menekankan kewajiban pemerintah pusat dan pemerintah daerah untuk menjamin terselenggaranya pendidikan tanpa diskriminatif. Lihat Direktorat Jendral Pendidikan Islam Departemen Agama RI, Undang-undang dan Peraturan Pemerintah tentag Pendidikan, (Jakarta: DEPAG RI, 2006), 9, 11. 
Di samping itu kompetensi dasar dan indikator-indikatornya akan membantu anak memahami apa yang harus mereka kuasai. ${ }^{13}$ Berpangkal pada pendekatan ini pemerintah kemudian mengembangkan Kurikulum Tingkat Satuan Pendidikan yang memberikan otonomi bagi tiap satuan pendidikan untuk menyusun dan mengembangkan sendiri kurikulumnya berdasarkan karakteristik peserta didik dan kepentingan daerah masing-masing. Kebijakan ini bukan berarti menghilangkan unsurunsur nasional dan menimbulkan fanatisme daerah, tetapi dalam rangka memberikan perimbangan yang proporsional antara kurikulum nasional dan daerah (lokal).

\section{B. Peningkatan kualitas pembelajaran}

Peningkatan kualitas pembelajaran harus dilakukan agar mencapai peningkatan kualitas hasil pendidikan. Faktor penentu utama keberhasilan upaya itu adalah pendidik. Di tangan pendidikan kurikulum akan hidup dan bermakna. Di tangan pendidik pula metode penyajian menjadi hidup dan menarik bagi peserta didik. Begitu pula alat pendidikan baik material maupun non material dapat digunakan oleh pendidik sesuai dengan kepentingan dan kebutuhannya.

Dengan demikian pendidik memegang kunci yang penting dalam upaya peningkatan kualitas pembelajaran. Semua pembaruan yang menyangkut upaya peningkatan kualitas pendidikan harus mempertimbangkan keikutsertaan. Michael G. Fullan (1991) dalam bukunya The New Meaning of Educational Change berpendapat "Educational Change depends on what teacher do and think-it's as simple and as complex as that. ${ }^{14}$ Keikutsertaan guru di sini bukan dalam arti fisik semata, tetapi yang lebih penting lagi keikutsertaan secara mental yang didukung oleh kemampuan profesionalnya. Dapat dikatakan upaya peningkatan hasil pendidikan harus dilakukan dengan peningkatan kualifikasi guru. Dalam rangka upaya ini pemerintah telah menerbitkan Undang-undang nomor 14 tahun 2005 tentang guru dan dosen, yang khusus mengatur tentang kualifikasi, kompetensi dan sertifikasi guru. ${ }^{15}$

Dengan kekuatan hukum ini diharapkan akan muncul guru-guru profesional yang kreatif mencari strategi dan pendekatan baru dalam pembelajaran. Pencarian pendekatan dan strategi inilah yang menimbulkan berbagai macam inovasi dalam pembelajaran. Diantara inovasi itu adalah adanya kecenderungan untuk mengedapkan pembelajaran yang berorientasi kepada peserta didik, dengan indikator keberhasilan terletak pada kesejahteraan anak didik. Anak didik sejahtera jika aktivitas belajarnya menyenangkan dan menggairahkan. Model pembelajaran seperti ini antara lain: humanizing of the classroom, active learning, quantum learning, quantum teaching, dan the accelerated learning.

${ }^{13}$ Nurhadi dan Agus Gerrad Senduk, Pembelajaran...., 2.

${ }^{14}$ Suyanto \& Djihad Hisyam, Refleksi....., 19.

${ }_{15}$ Peraturan ini terdapat pada Bab IV Pasal 8, 9, 10, 11, 12 dan 13. Lihat: Direktorat Jendral Pendidikan Islam Departemen Agama RI, Undang-undang......, 88-89. 
Humanizing of the classroom ini dilatarbelakangi oleh kondisi sekolah yang otoriter, tidak manusiawi, sehingga banyak menyebabkan peserta didik putus asa, yang akhirnya mengakhiri hidupnya alias bunuh diri. Kasus ini banyak terjadi di Amerika Serikat dan Jepang. Humanizing of the classroom ini dicetuskan oleh John P. Miller yang terfokus pada pengembangan model "pendidikan afektif". Pendidikan model ini bertumpu pada tiga hal:(1) menyadari diri sebagai suatu proses pertumbuhan yang sedang dan akan terus berubah, (2) mengenali konsep dan identitas diri, dan (3) menyatupadukan kesadaran hati dan pikiran. Perubahan yang dilakukan tidak terbatas pada substansi materi saja, tetapi yang lebih penting pada aspek metodologis yang dipandang sangat manusiawi. ${ }^{16}$

Active learning dicetuskan oleh Melvin L. Silberman. Asumsi dasar yang dibangun dari model pembelajaran ini adalah bahwa belajar bukan merupakan konsekuensi otomatis dari penyampaian informasi kepada siswa. Belajar membutuhkan keterlibatan mental dan tindakan sekaligus. Pada saat kegiatan belajar itu aktif, siswa melakukan sebagian besar pekerjaan belajar. Mereka mempelajari gagasan-gagasan, memecahkan berbagai masalah dan menerapkan apa yang mereka pelajari.

Dalam active learning, cara belajar dengan mendengarkan saja akan cepat lupa, dengan cara mendengarkan dan melihat akan ingat sedikit, dengan cara mendengarkan, melihat, dan mendiskusikan dengan siswa lain akan paham, dengan cara mendengar, melihat, diskusi, dan melakukan akan memperoleh pengetahuan dan ketrampilan, dan cara untuk menguasai pelajaran yang terbagus adalah dengan mengajarkan. Belajar aktif merupakan langkah cepat, menyenangkan, dan menarik. Active learning menyajikan 101 strategi pembelajaran aktif yang dapat diterapkan hampir untuk semua materi pembelajaran. ${ }^{17}$

Adapun quantum learning merupakan cara pengubahan bermacam-macam interaksi, hubungan dan inspirasi yang ada di dalam dan di sekitar momen belajar. Dalam prakteknya, quantum learning menggabungkan sugestologi, teknik pemercepatan belajar dan neurolinguistik dengan teori, keyakinan, dan metode tertentu. Quantum learning mengasumsikan bahwa jika siswa mampu menggunakan potensi nalar dan emosinya secara jitu akan mampu membuat loncatan prestasi yang tidak bisa terduga sebelumnya. Dengan metode belajar yang tepat siswa bisa meraih prestasi belajar secara berlipat-ganda. Salah satu konsep dasar dari metode ini adalah belajar itu harus mengasyikkan dan berlangsung dalam suasana gembira, sehingga pintu masuk untuk informasi baru akan lebih besar dan terekam dengan baik.

Sedang quantum teaching berusaha mengubah suasana belajar yang monoton dan membosankan ke dalam suasana belajar yang meriah dan gembira dengan memadukan potensi fisik, psikis, dan emosi siswa menjadi suatu kesatuan kekuatan yang integral.

${ }^{16}$ Abd. Rachman Assegaf, dkk, "Kondisi dan Pemicu Kekerasan dalam Pendidikan" dalam: http/:: www.ditpertais.net, tanggal 2 Maret 2002.

${ }^{17}$ Hisyam Zaini, dkk, Desain Pembelajaran di Perguruan Tinggi, (Yogyakarta: CTSD IAIN Sunan Kalijaga, 2002), 112. 
Quantum teaching berisi prinsip-prinsip sistem perancangan pengajaran yang efektif, efisien, dan progresif berikut metode penyajiannya untuk mendapatkan hasil belajar yang mengagumkan dengan waktu yang sedikit. Dalam prakteknya, model pembelajaran ini bersandar pada asas utama bawalah dunia mereka ke dunia kita, dan antarkanlah dunia kita ke dunia mereka. Pembelajaran, dengan demikian merupakan kegiatan full content yang melibatkan semua aspek kepribadian siswa (pikiran, perasaan, dan bahasa tubuh) di samping pengetahuan, sikap, dan keyakinan sebelumnya, serta persepsi masa mendatang. Semua ini harus dikelola sebaik-baiknya, diselaraskan hingga mencapai harmoni (diorkestrasi). ${ }^{18}$

The accelerated learning merupakan pembelajaran yang dipercepat. Konsep dasar dari pembelajaran ini adalah bahwa pembelajaran itu berlangsung secara cepat, menyenangkan, dan memuaskan. Pemilik konsep ini, Dave Meier menyarankan kepada guru agar dalam mengelola kelas menggunakan pendekatan Somatic, Auditory, Visual, dan Intellectual (SAVI). Somatic dimaksudkan sebagai learning by moving and doing (belajar dengan bergerak dan berbuat). Auditory adalalah learning by talking and hearing (belajar dengan berbicara dan mendengarkan). Visual diartikan learning by observing and picturing (belajar dengan mengamati dan mengambarkan). Intellectual maksudnya adalah learning by problem solving and reflecting (belajar dengan pemecahan masalah dan melakukan refleksi). Bobbi DePorter menganggap accelerated learning dapat memungkinkan siswa untuk belajar dengan kecepatan yang mengesankan, dengan upaya yang normal dan dibarengi kegembiraan. Cara ini menyatukan unsur-unsur yang sekilas tampak tidak mempunyai persamaan, tampak tidak mempunyai persamaan, misalnya hiburan, permainan, warna, cara berpikir positif, kebugaran fisik dan kesehatan emosional. Namun semua unsur ini bekerja sama untuk menghasilkan pengalaman belajar yang efektif. ${ }^{19}$

Berbagai inovasi di atas dilakukan dengan tujuan agar pendidikan dapat berdaya guna dan berhasil guna. Akan tetapi dalam pelaksanaan inovasi itu sendiri ada beberapa hal yang harus diperhatikan sebagai berikut;

1. Inovasi yang dilakukan harus sesuai dengan karakteristik peserta didik sehingga mempunyai implikasi positif bagi kemudahan belajar peserta didik.

2. Tidak ada satu inovasi pun yang bisa dianggap paling benar sepanjang belum dapat dibuktikan efektifitas dan efisiensinya terhadap hasil belajar yang diharapkan sesuai dengan kebutuhan peserta dididk dalam kurun waktu tertentu. Oleh karena itu setiap inovasi harus terus dilaksanakan sampai berhasil.

3. Inovasi selalu diwarnai dengan ketidakpastian mengenai efektifitasnya terhadap kualitas pembelajaran. Oleh karena itu perlu disadarai bahwa inovasi yang berhasil di suatu tempat belum tentu berhasil di tempat lain.

\footnotetext{
${ }^{18}$ Luk-luk Nur Mufidah, "Pembelajaran Kuantum.......

${ }^{19}$ Abd. Rachman Assegaf, dkk, "Kondisi.
} 
4. Inovasi dalam pembelajaran dapat dilaksanakan baik pada sektor pendidikan formal, nonformal maupun informal pada segala macam bentuk jalur dan jenjang pendidikan yang terkait dengan berbagai bidang kehidupan.

\section{KESIMPULAN}

Inovasi pendidikan merupakan proses yang akan terus terjadi karena didorong oleh adanya faktor luar dan faktor dari dalam diri manusia sendiri serta adanya interaksi antara keduanya. Faktor dari dalam diri misalnya keinginan dan kebutuhan serta adanya potensi untuk meningkatkan dan memenuhi kebutuhan hidupnya. Sedang faktor luar adalah perubahan-perubahan yang terjadi di lingkungan kehidupan manusia sendiri. Interaksi antara faktor dari luar dan dari dalam ini meyebabkan terjadinya perkembangan ilmu pengetahuan dan teknologi serta adanya inovasi yang tiada henti. Dikarenakan pendidikan merupakan sarana untuk membentuk manusia menjadi pribadi unggul yang siap menghadapi tantangan zaman, maka pendidikan juga harus siap merespon segala perubahan zaman itu sendiri, sehingga dapat dikatakan bahwa inovasi dalam dunia pendidikan merupakan sebuah keharusan.

\section{DAFTAR PUSTAKA}

Ashby, Aric. The Fourth Revolution, Instructional Technology in Higher Education. New York: Carnegie Commision in Higher Education, 1972.

Assegaf, Abd. Rachman, dkk, "Kondisi dan Pemicu Kekerasan dalam Pendidikan" dalam: http//: www.ditpertais.net, tanggal 2 Maret 2002.

Daulay, Haidar Putra. Pendidikan Islam dalam Sistem Pendidikan Nasional di Indonesia. Jakarta: Prenada media, 2004.

Direktorat Jendral Pendidikan Islam Departemen Agama RI.

Undang-undang dan Peraturan Pemerintah tentag Pendidikan.Jakarta: DEPAG RI, 2006.

Ihsan, Fuad. Dasar-dasar Kependidikan. Jakarta: Rineka Cipta, 2005.

Nurhadi dan Agus Gerrad Senduk. Pembelajaran Kontekstual dan Penerapannya dalam KBK. Malang: Penerbit Universitas Negeri Malang. 2003

Nur Mufidah, Luk-luk, "Pembelajaran Kuantum yang Menyenangkan", dalam http: //pakb.wordpress (2 April 2008)

Saylor, Galen J and Alexander M. William. Curriculum Planing for Better Teaching and Learning, New York: Holt, Rinchat, 1960.

Suyanto \& Djihad Hisyam. Refleksi dan reformasi Pendidikan di Indonesia Memasuki Milenium III. Yogyakarta: Adicita KaryaNusantara, 2000. 
Warsita, Bambang. Teknologi Pembelajaran, Landasan dan Aplikasinya. Jakarta: Rineka Cipta, 2008.

Wicaksono, Rohadi. "Mengapa Harus Konstruktivistik", dalam http//www.artikelpendidikan.com (19 Juli 2007).

Zaini, Hisyam, dkk, Desain Pembelajaran di Perguruan Tinggi. Yogyakarta: CTSD IAIN Sunan Kalijaga, 2002. 